\title{
AUDIT ENERGI DAN ANALISA PELUANG PENGHEMATAN KONSUMSI ENERGI PADA SISTEM AIR CONDITIONING DI RUANGAN LABORATORIUM FAKULTAS TEKNIK UNIVERSITAS NURUL JADID
}

\author{
Muhammad Sayuti ${ }^{1}$, Amalia Herlina ${ }^{2}$, Maman Pribadi ${ }^{3}$ \\ ${ }^{a, b, c}$ Fakutas Teknik Universitas Nurul Jadid \\ E-mail: sayuti.iyudt99@gmail.com ${ }^{1)}$, amaliaherlina1810@gmail.co ${ }^{2)}$, palem.pribadi@gmail.com ${ }^{3)}$.
}

\begin{abstract}
Air Conditioning merupakan suatu peralatan yang digunakan untuk mengkondisikan udara sehingga dapat mencapai temperatur dan kelembaban yang sesuai dengan kondisi udaranyaman sesuai Standar Nasional Indonesia (SNI) 03-65722001. Audit energi adalah kegiatanuntuk mengidentifikasi seberapa banyak energi yang digunakan serta langkah-langkah yang diperlukan untuk menghemat energi pada fasilitas energi tersebut. Energi listrik digunakan untuk menyalakan alat-alat elektronik salah satunya Air Conditioning. Ada beberapa ruangan yang menggunakan Air Conditioning di Fakultas Teknik Universitas Nurul Jadid salah satunya yaitu di Ruangan Laboratorium yang paling banyak penggunaan konsumsinya. Penelitian ini bertujuan untuk mengetahui penggunaan energi listrik dengan menghitung intensitas konsumsi energi (IKE), mencari kebutuhan air conditioning disetiap ruangannya dengan menghitung british thermal unit (BTU) dan besar estimasi kebutuhan Air Conditioning terhadap masing-masing ruangannya serta menganalisa peluang penghematan konsumsi energi pada Air Conditioning di Laboratorium Fakultas Teknik Universitas Nurul Jadid.

Berdasarkan hasil pengukuran intensitas konsumsi energi (IKE) awal menunjukkan bahwa penggunaan energi listrik di Ruangan Laboratorium Fakultas Teknik Universitas Nurul Jadid adalah 99,034 $\mathrm{kWh} / \mathrm{bulan}$ dengan setting ac remote ruangan $16^{\circ} \mathrm{C}$ terdapat suhu ruangan $24^{\circ} \mathrm{C}$ selama $6 \mathrm{Jam}$, Kemudian setelah menganalisa peluang penghematannya terdapat nilai 64,86 $k W h / b u l a n$ dengan setting ac remote $16^{\circ} \mathrm{C}$ untuk mencapai suhu ruangan $22^{\circ} \mathrm{C}$ selama 4 jam. Hasil perhitungan british thermal unit (BTU) menunjukkan kebutuhan Air Conditioning menurut ruangannya sudah memenuhi standarisasi pemakaiannya, tetapi kurang stabil. Kemudian peluang penghematannya untuk melakukan penyeimbangan beban, mengurangi jam operasinya, matikan Air Conditioning apabila sudah digunakan.
\end{abstract}

Kata Kunci - Audit Energi, Sistem Air Conditioning, Standart IKE.

\section{PENDAhuluan}

Temperatur udara rata-rata di Indonesia yang terletak di daerah khatulistiwa dan beriklim tropis adalah sekitar $26,96^{\circ} \mathrm{C}$ dengan kelembapan relatif atau relative humidity $(\mathrm{RH})$ ratarata sekitar $80,8 \%$. Pada musim kemarau, temperatur maksimal rata-rata mencapai sekitar $34,12^{\circ} \mathrm{C}$, namun di beberapa tempat dapat mencapai $40^{\circ} \mathrm{C}$. Dengan kondisi tersebut, kebutuhan pengkondisian udara atau air conditioning (AC) di Indonesia sangat diperlukan untuk menunjang kenyamanan dalam beraktifitas di dalam ruangan sesuai dengan Standar Nasional Indonesia (SNI) bahwa suhu nyaman antara $24^{\circ} \mathrm{C}$ hingga $27^{\circ} \mathrm{C}$ dan kelembapan relatif $60 \% \pm 5 \%$ (Suntoro, S, \& Ahadi, 2018).

Berdasarkan penjelasan di atas, daerah Paiton Probolinggo dan sekitarnya ialah termasuk daerah dengan suhu di atas rata-rata suhu nyaman karena berada di daerah pinggir pantai. Hal tersebut memberi dampak negatif mengingat banyaknya perkantoran dan lembaga sekolah di daerah Paiton - Probolinggo, sehingga kenyamanan dalam beraktivitas dapat terganggu, seperti konsentrasi karyawan di perkantoran yang kurang maksimal, proses belajar mengajar yang kurang efektif dan contoh lainnya, yang semuanya disebabkan oleh panasnya suhu lingkungan. Contoh konkret saat ini ialah di lembaga Universitas Nurul Jadid (UNUJA) yang memiliki beberapa gedung Fakultas yang diantaranya sudah terfasilitasi AC (Air Conditioning) demi kenyamanan proses belajar mengajar. Salah satu penerapan AC (Air conditioning) di dalam kelas ialah di Fakultas Teknik, tepatnya di masing-masing ruang laboratorium komputer.

Besarnya biaya yang harus dikeluarkan untuk pengoperasian AC ini tergantung berapa lama ia dioperasikan. Berdasarkan Standar Nasional Indonesia SNI. Konsumsi Energi adalah besar energi yang digunakan oleh bangunan gedung dalam periode waktu tertentu dan merupakan perkalian antara daya dan waktu operasi. Besarnya konsumsi energi yang dibutuhkan untuk mengoperasikan alat pendingin udara (AC) dapat diketahui dengan demikian biaya operasi dan energi dapat dihemat (Syamsuri Hasan, Maman Rakhman, dkk.).

Berdasarkan Peraturan Menteri Energi dan Sumber Daya Mineral Republik Indonesia Nomor 13 Tahun 2012 tentang penghematan pemakaian tenaga listrik, Maka mengingat pemakaian energi listrik untuk AC yang tidak sedikit, perlu rasanya Fakultas Teknik Universitas Nurul Jadid melakukan audit energi dan Analisa Peluang Penghematan Konsumsi Energi Pada Sistem Air Conditioning di masing-masing Laboratorium.

Dari paparan di atas, maka penulis berinisitaif untuk melakukan penelitian dengan judul Audit Energi Dan Analisa Peluang Penghematan Konsumsi Energi Pada Sistem Air Conditioning Di Ruangan Laboratorium Fakultas Teknik Universitas Nurul Jadid. Sehingga, dapat menjawab permasalahan yang ada.

\section{TINJAUAN PUSTAKA}

Menurut W.F. Stoecker (1996), pengkondisian udara adalah proses perlakuan terhadap udara untuk mengatut suhu 
kelembaban, kebersihan dan pendistribusiannya secara serentak guna mencapai kondisi nyaman yang dibutuhkan oleh penghuni yang berada didalamnya.

Menurut Wiranto Arismunandar (1991), penyegaran udara adalah proses mendinginkan udara sehingga dapat mencapai temperatur dan kelembaban yang sesuai dengan yang

dipersyaratkan terhadap kondisi udara dari suatu ruangan tertentu. Selain itu, untuk mengatur aliran udara dan kebersihannya (Syahrizal, Panjaitan, \& Udara, 2013).

Bangunan gedung modern menggunakan berbagai sarana untuk memberi kenyamanan bagi penghuni dan tamunya. Sarana yang memberikan kenyamanan ini disebut dengan utilitas bangunan dengan distribusi pemakaian listrik dan sistem tata udara adalah konsumen pemakai listrik terbesar. Pada dasarnya sistem tata udara terbagi menjadi 2, yaitu :

a. Sistem tata udara langsung (Direct Cooling).

Pada sistem ini udara diturunkan suhunya oleh refrigran freon dan disalurkan ke dalam ruangan tanpa saluran udara (ducting). Jenis yang digunakan adalah AC Window berkapasitas 0,5 - $2 \mathrm{pk}$, AC split berkapasitas 0,5 - 3 pk dan AC package berkapasitas sampai 10 pk.

b. Sistem tata udara tidak langsung (Indirect Cooling).

Refrigran yang digunakan bukan freon tetapi air es (chilled water) dengan suhu sekitar 50C. Air es dihasilkan dalam chiller (mesin pembuat es yang menggunakan refrigran sebagai zat pendingin). Sistem ini dikenal dengan sistem tata udara terpusat (Central Air Conditioning System).

Rekomendasi dari Standar Nasional Indonesia (SNI) 036572-2001, menyebutkan bahwa daerah kenyamanan suhu untuk daerah tropis dapat dibagi menjadi :

1. Sejuk, antara temperatur $20,5^{\circ} \mathrm{C}-22,8^{\circ} \mathrm{C}$

2. Nyaman, antara temperatur $22,8^{\circ} \mathrm{C}-25,8^{\circ} \mathrm{C}$

3. Hangat, antara temperatur $25,8^{\circ} \mathrm{C}-27,1^{\circ} \mathrm{C}$

Hubungan Beban Air Conditioning Dengan Ruangan. Kebutuhan air conditioner dalam suatu ruangan dihitung dalam satuan BTU (British Thermal Unit) per hour atau ditulis BTU/hr. Satuan BTU/hr merupakan satuan energi yang digunakan di Amerika Serikat yang didefinisikan sebagai jumlah energi untuk meningkatkan atau menurunkan suhu sebesar $1^{\circ}$ F. Selain itu, perusahaan air conditioner menggunakan satuan PK dalam menilai daya air conditioner untuk suatu ruangan. Dalam konversi satuan daya 9000 $\mathrm{BTU} / \mathrm{hr}=1 \mathrm{PK}=0,746 \mathrm{~kW}$ Beberapa daya air conditioner yang diproduksi secara umum oleh perusahaan air conditioner antara lain:

1. $5000 \mathrm{BTU} / \mathrm{hr}=1 / 2 \mathrm{PK}$, kode angka: 5

2. $7000 \mathrm{BTU} / \mathrm{hr}=3 / 4 \mathrm{PK}$, kode angka: 7

3. $9000 \mathrm{BTU} / \mathrm{hr}=1 \mathrm{PK}$, kode angka: 9

4. $12000 \mathrm{BTU} / \mathrm{hr}=1,5 \mathrm{PK}$, kode angka: 12

5. $18000 \mathrm{BTU} / \mathrm{hr}=2 \mathrm{PK}$, kode angka: 18

6. $24000 \mathrm{BTU} / \mathrm{hr}=2,5 \mathrm{PK}$, kode angka: 24

Jika suatu ruangan ingin dipasang air conditioner, konsumen perlu memperhitungkan berapa besar kebutuhan air conditioner untuk ruangan tersebut. Kebutuhan air conditioner untuk sebuah ruangan dapat diperhitungkan dengan rumus sebagai berikut :

$$
\text { :Estimasi Beban AC }(B T U / h r)=\frac{(P . L . T . I . E)}{60}
$$

Keterangan:

P: Panjang ruangan (dalam satuan kaki/feet).

L : Lebar ruangan (dalam satuan kaki/feet).

$\mathrm{T}$ : Tinggi ruangan (dalam satuan kaki/feet).

I :Nilai 10 jika ruang berinsulasi (berada di lantai bawah, atau berhimpit dengan ruang lain), nilai 18 jika ruang tidak berinsulasi (di lantai atas).

E :Nilai 16 jika jendela menghadap ke utara; nilai 17 jika menghadap ke timur; nilai 18 jika menghadap ke selatan; dan nilai 20 jika menghadap ke barat.

1 meter $=3,28$ feet dan $1 \mathrm{~m}^{2}=10,76 \mathrm{ft}^{2}$

Dikatakan dalam konservasi energi menurut SNI 6390:2011, yaitu Konservasi energi sistem tata udara bangunan gedung, adalah upaya sistematis, terencana, dan terpadu untuk melestarikan sumber daya energi dalam negeri serta meningkatkan efisiensi pemanfaatannya tanpa mengorbankan tuntutan kenyamanan manusia dan atau menurunkan kinerja alat. (Riyadi \& Tambunan, 2013).

Audit energi pada sebuah bangunan merupakan suatu bentuk studi kelayakan. Selain untuk mengidentifikasi penggunaan energi dan peluang penghematan energi, audit energi juga merupakan suatu bentuk awal untuk melakukan program managemen energi. Program managemen energi ini merupakan suatu program yang sistematik dimana akan terjadi control terhadap kebiasaan penggunaan energi dan mengurangi pemborosan penggunaan energi (Lukman, 2018).

Intensitas Konsumsi Energi (Energy Use Intensity) atau IKE (EUI) berdasarkan formula perhitungan dalam Peraturan Gubernur No. 38 tahun 2012 adalah besar energi yang digunakan suatu bangunan gedung per luas area yang dikondisikan dalam satu bulan atau satu tahun.

TABEL I

STANDAR IKE BANGUNAN INDONESIA

\begin{tabular}{|l|l|l|}
\hline Kriteria & $\begin{array}{l}\text { Ruangan AC } \\
\mathbf{k W h} / \mathbf{m} 2 / \text { Bulan }\end{array}$ & $\begin{array}{l}\text { Ruangan Non AC } \\
\mathbf{k w H / m 2 / b u l a n}\end{array}$ \\
\hline $\begin{array}{l}\text { Sangat } \\
\text { Efisien }\end{array}$ & $4,17-7,92$ & $0,84-1,67$ \\
\hline Efisien & $7,92-12,08$ & $1,67-2,5$ \\
\hline $\begin{array}{l}\text { Cukup } \\
\text { Efisien }\end{array}$ & $12,08-14,58$ & - \\
\hline Agak Boros & $14,58-19,17$ & - \\
\hline Boros & $19,17-23,75$ & $2,5-3,34$ \\
\hline Sangat Boros & $23,75-37,75$ & $3,34-4,17$ \\
\hline
\end{tabular}

Intensitas Konsumsi Energi (IKE) Listrik Indikator utama penghematan energi di sebuah gedung umumnya menggunakan Intensitas Konsumsi Energi (IKE). IKE 
menunjukkan besarnya konsumsi energi $(\mathrm{kWh})$ per meter persegi (m2) setiap bulan. Angka IKE (kWh/m2/bulan) diperoleh dengan membagi jumlah $\mathrm{kWh}$ penggunaan listrik selama sebulan dengan luas bangunan yang digunakan. Untuk perhitungan IKE direkomendasikan melalui Permen ESDM No.13 Tahun 2012 akan menentukan apakah sebuah bangunan tergolong sangat efisien, efisien, cukup efisien dan boros, seperti tabel berikut ini.

TABEL II

KRITERIA IKE BANGUNAN GEDUNG TIDAK BER-AC (SALPANIO, N.D.)

\begin{tabular}{|c|c|}
\hline Kriteria & Keterangan \\
\hline $\begin{array}{c}\text { Sangat Efisien } \\
(4,17-7,92) \\
\mathrm{kWh} / \mathrm{m}^{2} / \text { bulan }\end{array}$ & $\begin{array}{l}\text { a) Desain gedung sesuai standar tatacara } \\
\text { perencanaan teknis konservasi energi } \\
\text { b) Pengoperasian peralatan energi } \\
\text { dilakukan dengan prinsip-prinsip } \\
\text { management energi }\end{array}$ \\
\hline $\begin{array}{c}\text { Efisien } \\
(7,93-12,08) \\
\mathrm{kWh} / \mathrm{m}^{2} / \text { bulan }\end{array}$ & \begin{tabular}{|l|} 
a) Pemeliharaan gedung dan peralatan \\
energi dilakukan sesuai prosedur \\
b) Efisiensi penggunaan energi masih \\
mungkin ditingkatkan melalui \\
penerapan system manajemen energi \\
terpadu
\end{tabular} \\
\hline $\begin{array}{l}\text { Cukup Efisien } \\
(12,08-14,58) \\
\mathrm{kWh} / \mathrm{m}^{2} / \text { bulan }\end{array}$ & $\begin{array}{l}\text { a) Penggunaan energi cukup efisien } \\
\text { melalui pemeliharaan bangunan dan } \\
\text { peralatan energi masih memungkinkan } \\
\text { b) Pengoperasian dan pemeliharaan gedung } \\
\text { belum mempertimbangkan prinsip } \\
\text { konservasi energi }\end{array}$ \\
\hline $\begin{array}{c}\text { Agak Boros } \\
(14,58-19,17) \\
\mathrm{kWh} / \mathrm{m}^{2} / \text { bulan }\end{array}$ & \begin{tabular}{|l|} 
a) Audit energi perlu dipertimbangkan \\
untuk menentukan perbaikan efisiensi \\
yang mungkin dilakukan \\
b) Desain bangunan maupun pemeliharaan \\
dan pengoperasian gedung belum \\
mempertimbangkan konservasi energi
\end{tabular} \\
\hline
\end{tabular}

TABEL III

KRITERIA IKE BANGUNAN GEDUNG BER-AC (SALPANIO, N.D.).

\begin{tabular}{|c|c|}
\hline Kriteria & Keterangan \\
\hline $\begin{array}{c}\text { Efisien } \\
(0,84-1,67) \\
\mathrm{kWh} / \mathrm{m}^{2} / \text { bulan }\end{array}$ & $\begin{array}{l}\text { a) Pengeloaan gedung dan peralatan energi } \\
\text { dilakukan dengan prinsip konversi } \\
\text { energi listrik } \\
\text { b) Pemeliharaan peralatan energi } \\
\text { dilakukan sesuai dengan prosedur } \\
\text { c) Efisiensi pengguanaan energi masih } \\
\text { mungkin ditingkatkan melalui } \\
\text { penerapan system manajemen energi } \\
\text { terpadu }\end{array}$ \\
\hline $\begin{array}{l}\text { Cukup Efisien } \\
(1,67-2,5) \\
\mathrm{kWh} / \mathrm{m}^{2} / \text { bulan }\end{array}$ & $\begin{array}{l}\text { a) Penggunaan energi cukup efisien namun } \\
\text { masih memiliki peluang konservasi } \\
\text { nergi } \\
\text { b) Perbaikan efisiensi melalui } \\
\text { pemeliharaan bangunan dan peraltan } \\
\text { nergi masih dimungkinkan }\end{array}$ \\
\hline $\begin{array}{c}\text { Boros } \\
(2,5-3,34) \\
\mathrm{kWh} / \mathrm{m}^{2} / \text { bulan }\end{array}$ & $\begin{array}{l}\text { a) Audit energi perlu dilakukan } \\
\text { untukmenentukan langkah-langkah } \\
\text { pernbaikan sehingga pemborosan energi } \\
\text { dapat dihindari } \\
\text { b) Desain bangunan maupun pemeliharaan } \\
\text { dan pengoperasian gedung belum } \\
\text { mempertimbangkan konservasi energi }\end{array}$ \\
\hline $\begin{array}{c}\text { Sangat Boros } \\
(3,34-4,17) \\
\mathrm{kWh} / \mathrm{m}^{2} / \text { bulan }\end{array}$ & $\begin{array}{l}\text { a) Instalasi peralatan, desain } \\
\text { pengoperasian dan pemeliharaan tidak } \\
\text { mengacu pada penghematan energi } \\
\text { b) Agar dilakukan peninjauan ulang atas } \\
\text { semua instalasi /peralatan eenergi serta } \\
\text { penerapan managemen energi dalam } \\
\text { pengelolaan bangunan } \\
\text { c) Audit energi adalah langkah awal yang } \\
\text { perlu dilakukan }\end{array}$ \\
\hline
\end{tabular}

Standar IKE yang digunakan sebagai rujukan tingkat penggunaan energi gedung dapat berbeda-beda, dipengaruhi oleh pendekatan analisa dan sampel gedung yang diambil dalam proses perumusan standar tersebut. Berikut contoh Intensitas Konsumsi Energi (rata-rata) untuk Gedung Kantor dari berbagai sumber:

Bila nilai IKE hasil perhitungan telah dibandingkan dengan target IKE dan hasilnya ternyata sama atau kurang dari target IKE, maka kegiatan audit selanjutnya dapat dihentikan atau diteruskan dengan harapan diperoleh nilai IKE yang lebih rendah lagi. Konsumsi energi secara spesifik dapat dirumuskan sebagai berikut :

$$
I K E=\frac{\text { Total Konsumsi Energi }(\text { KWH total })}{\text { Luas Bangunan }}
$$

Penelitian ini dilakukan di Ruagan Laboratorium Fakultas Teknik Universitas Nurul Jadid, dimana pada ruangan laboratorium tersebut memiliki 9 ruangan, yang terdiri dari 5 laboratorium komputer, 3 laboratorium elektro dan 1 laboratorium jaringan, setiap ruangan terdiri dari $3 \mathrm{AC}$ dan 2 AC jika dijumlahkan terdapat 24 AC yang terpasang di laboratorium fakultas teknik universitas nurul jadid, setiap ruangan yang difungsikan untuk proses perkuliahan di gedung laboratorium fakultas teknik universitas nurul jadid memiliki kriteria ruangan yang sama. Yaitu panjang dan lebar ruangan yang sama serta peletakan dan jumlah air conditioning (AC) yang sama serta merk AC yang digunakan di setiap ruangan laboratorium hampir sama. 


\section{METODE PENELITIAN}

Metode penelitian merupakan suatu proses analisis dan pengumpulan data dari penelitian yang dibuat.

Metode penelitian yang digunakan dalam penelitian ini adalah studi literatur, observasi, dan konservasi energi.

Studi literatur dilakukan untuk :

1. Mempelajari konsep audit energi listrik air conditioning.

2. Mempelajari perhitungan Intensitas Konsumsi Energi Listrik (IKE) air conditioning

3. Mempelajari peluang penghematan energi listrik air conditioning untuk mencapai efisiensi energi listrik.

Konservasi energi merupakan peningkatan efisiensi energi yang digunakan atau proses penghematan energi. Dalam proses ini melibatkan adanya audit energi yaitu suatu metode untuk menghitung tingkat konsumsi energi di suatu gedung atau bangunan yang mana hasilnya nanti akan dibandingkan dengan standar yang ada untuk kemudian dicari solusi penghematan konsumsi energi jika tingkat konsumsi energinya melebihi standar yang ada.

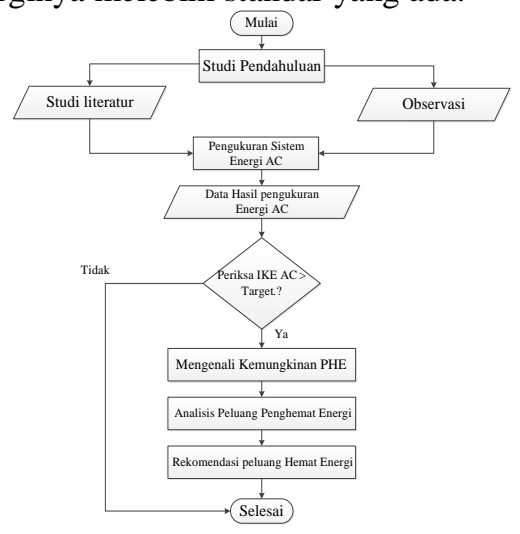

Gambar 1. Flowchart alur penelitian

1. Studi Pendahuluan

Studi pendahuluan adalah studi yang dilakukan untuk mengumpulkan data-data dan informasi tentang penelitian yang akan dilakukan. Kegiatan yang dilakukan pada studi penelitian untuk mengumpulkan informasi dan data-data terkait dengan penelitian adalah studi literatur dan observasi.

a. Observasi merupakan teknik pengumpulan data dengan melakukan pengamatan secara langsung ke objek penelitian untuk melihat dari dekat kegiatan yang dilakukan (Riduwan, 2004).

\section{Analisis Data}

Analisis data merupakan proses yang merinci usaha secara formal untuk menemukan tema dan merumuskan hipotesis (ide) seperti yang disarankan dan sebagai usaha untuk memberikan bantuan dan tema pada hipotesis (Taylor, 1975). Adapun kegiatan yang akan dilaksanakan dalam analisis data adalah sebagai berikut :

a. Analisis Sistem Air Conditioning Dan Nilai IKEPada tahap ini, peneliti melakukan analisis sistem air conditioning gedung dan nilai IKE pada kondisi gedung saat ini. Ditahap ini peneliti menganalisis data yang di ambil secara observasi.

b. Pengukuran Konsumsi Energi Sebagaimana yang disarankan Departemen Pertambangan dan Energi, audit energi pada bangunan gedung pada intinya terdiri dari dua bagian, yaitu audit energi awal dan audit energi rinci. Pada penelitian ini audit yang akan dilaksanakan adalah audit energi rinci terhadap air conditioner.

\section{Mengenali Peluang Hemat Energi (PHE)}

Hasil pengukuran selanjutnya ditindak lanjuti dengan perhitungan besarnya Intensitas Konsumsi Energi (IKE) listrik Air Conditioner dan penyusunan profil penggunaan energinya. Besarnya IKE Air Conditioner didapatkan dari hasil perhitungan dibandingkan dengan IKE target berdasarkan standar pemerintah. Apabila hasilnya ternyata tidak melebihi target maka kegiatan audit energi dapat dihentikan. Apabila peluang hemat energi telah dikenali maka perlu ditindak lanjuti dengan analisis peluang hemat energi, yaitu dengan cara membandingkan potensi perolehan hemat energi dengan biaya yang harus dibayar untuk pelaksanaan rencana penghematan energi yang direkomendasikan. Penghematan energi pada bangunan gedung tidak dapat diperoleh begitu saja dengan cara mengurangi kenyamanan penghuni ataupun produktivitas di lingkunan kerja. Perlu dilakukan usahausaha seperti: Mengurangi sekecil mungkin pemakaian energi (mengurangi $\mathrm{kW}$ dan jam operasi), memperbaiki kinerja peralatan, penggunaan sumber energi yang murah. (Purwito, Tadjuddin, \& Akbar, 2018).

\section{Optimasi Sistem Air Conditioning dan Nilai IKE}

Pada tahap ini peneliti memberikan optimasi sistem Air Conditioning dan nilai IKE yang sesuai untuk Ruangan Laboratorium Fakultas Teknik Universitas Nurul Jadid. Optimasi yang di berikan merupakan kesimpulan dari hasil analisis sistem Air Conditioning sesuai standarisasi. Sehingga hasil dari kedua analisis pada kondisi yang berbeda akan menghasilkan optimasi sistem Air Conditioning yang sesuai dengan kondisi ruangan gedung saat ini.

\section{IV.HASIL DAN PEMBAHASAN}

\section{Hasil}

Teknik pengambilan data yang dilakukan oleh peneliti adalah dengan observasi. Kegiatan observasi yang dilakukan meliputi pengukuran luas dan tinggi ruangan, pengukuran intensitas Air Conditioning.

Data yang telah di ambil dari hasil observasi kemudian akan di bahas dan di analisa untuk mendapatkan nilai yang memenuhi standar yang telah di tentukan.

2. Tabel Data Hasil Observasi

Tabel data hasil observasi merupakan tabel yang berisi data-data hasil pengukuran dan observasi di Ruangan Laboratorium Fakultas Teknik Universitas Nurul Jadid. Peneliti mengambil semua data yang menyangkut mengenai 
kebutuhan untuk analisa. Adapun tabel hasil dari observasi adalah sebagai berikut.

TABEL IV

DATA PEMBAYARAN LISTRIK GEDUNG FAKULTAS TEKNIK UNIVERSITAS NURUL JADID

\begin{tabular}{|l|l|l|}
\hline \multicolumn{1}{|c|}{ N } & Bulan & Total Pembayaran \\
\hline 1 & Januari 2019 & Rp. 3.169 .050 \\
\hline 2 & Februari 2019 & Rp. 8.076 .299 \\
\hline 3 & Maret 2019 & Rp. 6.686 .225 \\
\hline \multicolumn{2}{|r|}{ Rata-rata } & Rp. 10.305 .044 \\
\hline
\end{tabular}

TABEL $\mathrm{V}$

DATA HASIL OBSERVASI TIAP DAYA RUANGAN LABORATORIUM

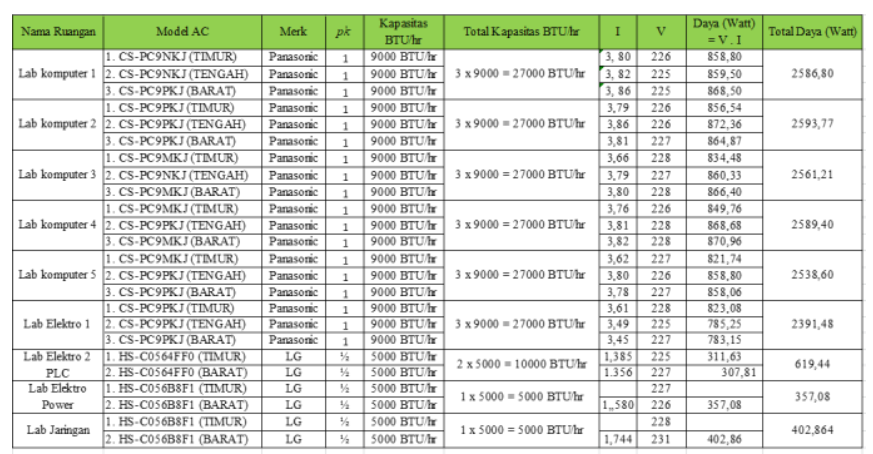

TABEL VI

DATA HASIL OBSERVASI PENGUKURAN RUANGAN DAN SUHU LABORATORIUM

\begin{tabular}{|c|c|c|c|c|c|c|c|c|c|}
\hline Nama Ruangan & Model AC & Merk & $\mathrm{P}$ & I & h & $p k$ & \begin{tabular}{|c|} 
Suhu \\
Remote \\
AC
\end{tabular} & $\begin{array}{c}\text { Suhu } \\
\text { Ruangan }\end{array}$ & $\mathrm{t}$ \\
\hline \multirow{3}{*}{ Lab komputer 1} & 1. CS-PC9NKJ(TIMUR) & Panasonic & \multirow{3}{*}{9} & \multirow{3}{*}{8} & \multirow{3}{*}{4} & 1 & \multirow{3}{*}{$16^{\circ} \mathrm{C}$} & \multirow{3}{*}{$24,7^{\circ} \mathrm{C}$} & \multirow{3}{*}{6} \\
\hline & 2. CS-PC9NKJ (TENGAH) & Panasonic & & & & 1 & & & \\
\hline & 3. CS-PC9PKJ (BARAT) & Panasonic & & & & 1 & & & \\
\hline \multirow{3}{*}{ Lab komputer 2} & 1. CS-PC9PKJ (TIMUR) & Panasonic & \multirow{3}{*}{9} & \multirow{3}{*}{8} & \multirow{3}{*}{4} & 1 & \multirow{3}{*}{$16^{\circ} \mathrm{C}$} & \multirow{3}{*}{$23,8^{\circ} \mathrm{C}$} & \multirow{3}{*}{6} \\
\hline & 2. CS-PC9PKJ (TENGAH) & Panasonic & & & & 1 & & & \\
\hline & 3. CS-PC9PKJ (BARAT) & Panasonic & & & & 1 & & & \\
\hline \multirow{3}{*}{ Lab komputer 3} & 1. CS-PC9MKJ (TIMUR) & Panasonic & \multirow{3}{*}{9} & \multirow{3}{*}{8} & \multirow{3}{*}{4} & 1 & \multirow{3}{*}{$16^{\circ} \mathrm{C}$} & \multirow{3}{*}{$24,7^{\circ} \mathrm{C}$} & \multirow{3}{*}{6} \\
\hline & 2. CS-PC9NKJ (TENGAH) & Panasonic & & & & 1 & & & \\
\hline & 3. CS-PC9MKJ (BARAT) & Panasonic & & & & 1 & & & \\
\hline \multirow{3}{*}{ Lab komputer 4} & 1. CS-PC9MKJ (TIMUR) & Panasonic & \multirow{3}{*}{9} & \multirow{3}{*}{8} & \multirow{3}{*}{4} & 1 & \multirow{3}{*}{$16^{\circ} \mathrm{C}$} & \multirow{3}{*}{$23,5^{\circ} \mathrm{C}$} & \multirow{3}{*}{6} \\
\hline & 2. CS-PC9PKJ (TENGAH) & Panasonic & & & & 1 & & & \\
\hline & 3. CS-PC9MKJ (BARAT) & Panasonic & & & & 1 & & & \\
\hline \multirow{3}{*}{ Lab komputer 5} & 1. CS-PC9MKJ (TIMUR) & Panasonic & \multirow{3}{*}{9} & \multirow{3}{*}{8} & \multirow{3}{*}{4} & 1 & & & \\
\hline & 2. CS-PC9PKJ (TENGAH) & Panasonic & & & & 1 & $16^{\circ} \mathrm{C}$ & $24,8^{\circ} \mathrm{C}$ & 6 \\
\hline & 3. CS-PC9PKJ (BARAT) & Panasonic & & & & 1 & & & \\
\hline & 1. CS-PC9PKJ (TIMUR) & Panasonic & & & & 1 & & & \\
\hline Lab Elektro 1 & 2. CS-PC9PKJ (TENGAH) & Panasonic & 9 & 8 & 4 & 1 & $16^{\circ} \mathrm{C}$ & $23,5^{\circ} \mathrm{C}$ & 6 \\
\hline & 3. CS-PC9PKJ (BARAT) & Panasonic & & & & 1 & & & \\
\hline Lab Elektro 2 & 1. HS-C0564FF0 (TIMUR) & LG & 9 & 8 & 4 & $1 / 2$ & $18^{\circ} \mathrm{C}$ & $27,5^{\circ} \mathrm{C}$ & 6 \\
\hline PLC & 2. HS-C0564FF0 (BARAT) & LG & 9 & 8 & 4 & $1 / 2$ & $18{ }^{\circ}$ & 21,20 & ${ }^{\circ}$ \\
\hline Lab Elektro & 1. HS-C056B8F1 (TIMUR) & LG & 4,5 & 8 & 4 & $\frac{1 / 2}{1 / 2}$ & $18^{\circ} \mathrm{C}$ & $28,7^{\circ} \mathrm{C}$ & 6 \\
\hline Power & 2. HS-C056B8F1 (BARAT) & $\frac{L G}{L G}$ & & & & & & $23,5^{\circ} \mathrm{C}$ & \\
\hline Lab Jaringan & $\begin{array}{l}\text { 1. HS-C0564FF0 (IIMUR) } \\
\text { 2. HS-C0564FF0 (BARAT) }\end{array}$ & LG & 4,5 & 8 & 4 & $1 / 2$ & $18^{\circ} \mathrm{C}$ & & 4 \\
\hline
\end{tabular}

3. Pembahasan

a. Analisis British Thermal Unit (BTU/hr)

Sample Pada Ruang Laboratorium Komputer 1

- Untuk Ruangan dengan Jumlah 3 AC Kapasitas 9000 per-pk

Diketahui :

$$
\begin{array}{llll}
\mathrm{P} & =9 \mathrm{~m}=29,53 \text { Feet } & \mathrm{I} & =10 \\
\mathrm{~L} & =8 \mathrm{~m}=26,24 \text { Feet } & \mathrm{E} & =18
\end{array}
$$$$
\mathrm{T} \quad=4 \mathrm{~m}=13,12 \text { Feet }
$$

Jawab

Estimasi Beban AC $($ BTU $/ h r)=\frac{(\text { P.L.T.I.E })}{60}$

Estimasi Beban AC (BTU/hr)

$$
\begin{gathered}
=\frac{(29,53 \times 26,24 \times 13,12 \times 10 \times 18)}{60} \\
\text { Estimasi Beban AC }(\text { BTU } / \mathrm{hr})=\frac{(1829926,38)}{60} \\
\text { Estimasi Beban AC }(\text { BTU / hr })=30498,773 \mathrm{Feet}(\text { BTU } / \mathrm{hr}) \\
=30499 \mathrm{Feet} /(\text { BTU } / \mathrm{hr}) .
\end{gathered}
$$

Jadi pada ruangan laboratorium komputer 1 diperoleh nilai intensitas british thermal unit sebesar 30499 Fett (/ BTU/hr). Kemudian pada ruangan tersebut terdapat 3 AC yang terpasang dan masing-masing 1 AC memiliki nilai 9000 BTU/hr,

Jika dijumlahkan total BTU/hr AC keseluruhannya maka terdapat nilai $27000 \mathrm{BTU} / \mathrm{hr}$ dengan kondisi AC beroperasi secara normal. Jadi perbandingan antara hasil pengukuran BTU/hr dengan yang sudah terpasang pada setiap ruangan tersubut terdapat selisih nilai -3499 dengan estimasi $1 / 2 \mathrm{pk}$, maka pada ruangan tersebut sudah efisien untuk di gunakan perkuliahan, hanya saja kurang stabil untuk memenuhi hasil yang sesuai dengan perhitungan BTU/hr.

Sample Pada Ruang Laboratorium Elektro 2 PLC

- Untuk Ruangan dengan Jumlah 2 AC Kapasitas 5000 per-pk

Diketahui :

$$
\begin{array}{llll}
\mathrm{P} & =9 \mathrm{~m}=29,53 \text { Feet } & \mathrm{I} & =10 \\
\mathrm{~L} & =8 \mathrm{~m}=26,24 \text { Feet } & \mathrm{E} & =16
\end{array}
$$$$
\mathrm{T} \quad=4 \mathrm{~m}=13,12 \text { Feet }
$$

Jawab :

Jawab :

Estimasi Beban AC $($ BTU $/ h r)=\frac{(\text { P.L.T.I.E })}{60}$

Estimasi Beban AC $(B T U / h r)$

$$
\begin{aligned}
& \qquad=\frac{(29,53 \times 26,24 \times 13,12 \times 10 \times 18)}{60} \\
& \text { Estimasi Beban AC }(\text { BTU } / \mathrm{hr})=\frac{(1829926,38)}{60} \\
& \text { Estimasi Beban AC }(\text { BTU / hr })=30498,773 \text { Feet }(B T U / h r) \\
& \quad=30499 \text { Feet / }(\text { BTU/ hr }) .
\end{aligned}
$$

Jadi pada ruangan laboratorium elektro 2 (PLC) diperoleh nilai intensitas british thermal unit sebesar 27110 Fett (/ BTU/hr). Kemudian pada ruangan tersebut terdapat 2 AC yang terpasang dan masing-masing $1 \mathrm{AC}$ memiliki nilai 5000 BTU/hr, jika dijumlahkan total BTU/hr AC keseluruhannya maka terdapat nilai $10000 \mathrm{BTU} / \mathrm{hr}$ dengan kondisi AC 
beroperasi secara normal. Jadi perbandingan antara hasil pengukuran BTU/hr dengan yang sudah terpasang pada ruangan tersubut terdapat selisih nilai -17110 dengan estimasi $2 \mathrm{pk}$, maka pada ruangan tersebut kurang efisien untuk di gunakan perkuliahan, dikarenakan kurang penambahan $1 \mathrm{AC}$ pada ruangan tersebut untuk mencapai efisien meskipun kurang stabil untuk memenuhi hasil yang sesuai dengan perhitungan BTU/hr.

TABEL VII

HASIL PENGUKURAN BTU/HR DISETIAP RUANGAN LABORATORIUM

\begin{tabular}{|c|c|c|c|c|c|c|c|c|c|c|c|}
\hline ModelaAC & Meath & p & 1 & b & 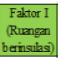 & \begin{tabular}{|c|c|} 
Fachtor \\
$E$
\end{tabular} & $\begin{array}{l}\text { Estimas } \\
\text { Burul }\end{array}$ & \begin{tabular}{|l} 
Esentuas \\
$p \hbar$
\end{tabular} & \begin{tabular}{|l|} 
BTVhr \\
YYang \\
Teppasarg
\end{tabular} & 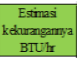 & $\begin{array}{c}\text { Estimasi } \\
p k\end{array}$ \\
\hline 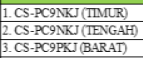 & $\begin{array}{l}\text { Parasonic } \\
\text { Parsaric } \\
\text { Pansonic }\end{array}$ & $9 \mathrm{~m}=29,53 \mathrm{ft}$ & $8 \mathrm{~m}=26,24 \mathrm{f}$ & $4 \mathrm{~m}=13,12 \mathrm{f}$ & 10 & 18 & $\begin{array}{l}30499 \\
\text { BTUhr }\end{array}$ & $3,5 p k$ & $\begin{array}{l}27000 \\
\text { BTUhrs }\end{array}$ & -3499 & $1 / 2$ \\
\hline 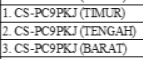 & $\begin{array}{l}\text { Parasonic } \\
\text { Parassonic } \\
\text { Pansonic }\end{array}$ & $9 \mathrm{~m}=29,53 \mathrm{ft}$ & $8 \mathrm{~m}=26.24 \mathrm{f}$ & $4 \mathrm{~m}=13,12 \mathrm{f}$ & 10 & 18 & $\begin{array}{l}30499 \\
\text { BTVhr }\end{array}$ & $3,5 p \hbar$ & $\begin{array}{l}27000 \\
\text { BTUhr }\end{array}$ & -3499 & $1 / 2$ \\
\hline 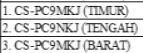 & $\begin{array}{l}\text { Parasonic } \\
\text { Parasanonic } \\
\text { Parasonic }\end{array}$ & $9 \mathrm{~m}=29,53 \mathrm{f}$ & $8 \mathrm{~m}=26.24 \mathrm{ft}$ & $4 \mathrm{~m}=13,12 \mathrm{f}$ & 10 & 18 & $\begin{array}{l}30499 \\
\text { BTUlir }\end{array}$ & $3,5 p \hat{k}$ & \begin{tabular}{|l}
27000 \\
BTChH
\end{tabular} & -3499 & $1 / 2$ \\
\hline 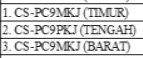 & $\begin{array}{l}\text { Parasonic } \\
\text { Parassonic } \\
\text { Pansonic }\end{array}$ & $9 \mathrm{~m}=29,53 \mathrm{f}$ & $8 \mathrm{~m}=20.24 \mathrm{ft}$ & $4 \mathrm{~m}=13,12 \mathrm{f}$ & 10 & 18 & $\begin{array}{l}30499 \\
\text { BTUlur }\end{array}$ & $3,5 p k$ & $\begin{array}{l}27000 \\
\text { BTUly }\end{array}$ & -3499 & $1 / 2$ \\
\hline 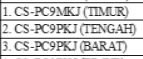 & $\begin{array}{l}\text { Parasonic } \\
\text { Parassonic } \\
\text { Parsonic }\end{array}$ & $9 \mathrm{~m}=29,53 \mathrm{f}$ & $8 \mathrm{~m}=26,24 \mathrm{ft}$ & $4 m=13,12 f$ & 10 & 18 & $\begin{array}{l}30499 \\
\text { BTUhir }\end{array}$ & $3,5 p k$ & $\begin{array}{l}27000 \\
\text { BTUhr }\end{array}$ & -3499 & $3 / 2$ \\
\hline 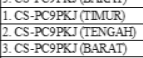 & 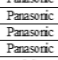 & $9 \mathrm{~m}=29,53 \mathrm{t}$ & $8 \mathrm{~m}=26,24 \mathrm{ft}$ & $4 \mathrm{~m}=13,12 \mathrm{f}$ & 10 & 18 & $\begin{array}{l}30499 \\
\text { BTUhir }\end{array}$ & $3,5 p k$ & $\begin{array}{l}27000 \\
\text { BTuhr } \\
\end{array}$ & -3499 & $3 / 2$ \\
\hline 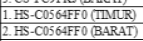 & $\frac{1 G}{L G}$ & $9 \mathrm{~m}=29,53 \mathrm{ft}$ & $8 \mathrm{~m}=26.24 \mathrm{I}$ & $4 \mathrm{~m}=13,12 \mathrm{f}$ & 10 & 16 & $\begin{array}{l}27110 \\
\text { BTUhr }\end{array}$ & $3 \mathrm{pk}$ & $\begin{array}{l}10000 \\
\text { BTUhr }\end{array}$ & -171110 & 2 \\
\hline 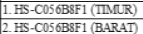 & $\frac{\text { LG }}{\text { IG }}$ & $-4.5 \mathrm{~m}=14,76 \mathrm{f}$ & $8 \mathrm{~m}=26,24 \mathrm{f}$ & $4 m=13: 12 f$ & 10 & 18 & $\begin{array}{l}15244 \\
\text { BTITH }\end{array}$ & $2 \mathrm{pk}^{\mathrm{k}}$ & $\begin{array}{l}5000 \\
\text { BTThr }\end{array}$ & -10244 & 1 \\
\hline 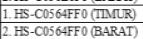 & $\frac{1 G}{L G G}$ & $4.5 \mathrm{~m}=14,76 \mathrm{f}$ & $8 \mathrm{~m}=26,24 \mathrm{ft}$ & $4 \mathrm{~m}=13,12 \mathrm{f}$ & 10 & 16 & $\begin{array}{l}13550 \\
\text { BTUhr }\end{array}$ & $1,5 \mathrm{pk}$ & $\begin{array}{l}5000 \\
\text { BTuhr }\end{array}$ & -8550 & 1 \\
\hline
\end{tabular}

b. Analisis Nilai IKE Pada Air Conditioning

Penggunaan daya yang digunakan oleh ruangan laboratorium fakultas teknik universitas nurul jadid dapat di analisis dengan tingkat intensitas konsumsi energi (IKE). Dari data yang telah di peroleh dari hasil observasi peneliti. Hasil dari analisa IKE pada gedung laboratorium fakultas teknik universitas nurul jadid adalah sebagai berikut.

Sample IKE Pada Ruangan Laboratorium Komputer 1

Diketahui :

$\mathrm{t} \quad=6 \mathrm{jam}$

$\Sigma \mathrm{W}=2587 \mathrm{~W}=2,587 \mathrm{~kW}$

Jawab :

$k W h=W \times t$

$k W h=2,587 \times 6$

$k W h=15,522$

Gedung fakultas teknik universitas nurul jadid memiliki daya yang terpasang sebesar

53.000 VA dengan golongan Sosial 2. Tarif dasar listrik untuk golongan S2 adalah sebesar Rp. 900/ kWh (sumber PLN 123). Jadi biaya yang di keluarkan oleh pihak lembaga untuk kebutuhan air conditioning pada ruangan laboratorium komputer 1 tersebut adalah 15,522 x 900 = Rp. 13.969,8/hari.

Jadi berdasarkan standar IKE bangunan indonesia yang ditetapkan oleh DEPDIKNAS, maka kriteria ruangan laboratorium komputer 1 yang memiliki nilai IKE sebesar 15,522 termasuk dalam katagori agak boros dengan nilai standar IKE yaitu 14,58 - 19,17.

Sample IKE Pada Ruangan Laboratorium Elektro 2 PLC Diketahui :

$$
\begin{aligned}
\mathrm{t} & =6 \mathrm{jam} \\
\Sigma \mathrm{W} & =619 \mathrm{~W}=0,619 \mathrm{~kW}
\end{aligned}
$$

Jawab :

$$
\begin{aligned}
& k W h=W \times t \\
& k W h=0,619 \times 6 \\
& k W h=3,714
\end{aligned}
$$

Gedung fakultas teknik universitas nurul jadid memiliki daya yang terpasang sebesar 53.000 VA dengan golongan Sosial 2. Tarif dasar listrik untuk golongan S2 adalah sebesar Rp. 900/ kWh (sumber PLN 123). Jadi biaya yang di keluarkan oleh pihak lembaga untuk kebutuhan air conditioning pada ruangan laboratorium elektro 2 PLC tersebut adalah 3,714 × $900=$ Rp. 3.342,6 /hari. Jadi berdasarkan standar IKE bangunan indonesia yang ditetapkan oleh DEPDIKNAS, maka kriteria ruangan laboratorium elektro 2 PLC memiliki nilai IKE sebesar 3,714 termasuk dalam katagori sangat efisien dengan nilai standar IKE yaitu $4,17-7,92$.

\begin{tabular}{|c|c|c|c|c|c|}
\hline No & Ruangan & $\Sigma$ PAC & $t$ & kWh & Biaya Perbulan \\
\hline 1 & Laboratorium Komputer 1 & 2587 & 6 & 15,52 & Rp419.094 \\
\hline 2 & Laboratorium Komputer 2 & 2594 & 6 & 15,56 & Rp420.228 \\
\hline 3 & Laboratorium Komputer 3 & 2561 & 6 & 15,37 & Rp414.882 \\
\hline 4 & Laboratorium Komputer 4 & 2589 & 6 & 15,53 & Rp419.418 \\
\hline 5 & Laboratorium Komputer 5 & 2539 & 6 & 15,23 & Rp411.318 \\
\hline 6 & Laboratorium Elektro 1 & 2391 & 6 & 14,35 & Rp387.342 \\
\hline 7 & Laboratorium Elektro 2 PLC & 619 & 6 & 3,71 & Rp100.278 \\
\hline 8 & \begin{tabular}{|l|} 
Laboratorium Power \\
\end{tabular} & 357 & 6 & 2,14 & Rp57.834 \\
\hline 9 & Laboratorium Jaringan & 403 & 4 & 1,61 & Rp43.524 \\
\hline \multicolumn{4}{|c|}{ Total Perbulan } & 99,03 & Rp2.673.918 \\
\hline
\end{tabular}

TABEL 8

JUMLAH PEMBIAYAAN DAYA PADA SISTEM AIR CONDITIONING RUANGAN LABORATORIUM FAKULTAS TEKNIK UNIVERSITAS NURUL JADID.

c. Mencari Peluang Penghematan Air Conditioning Di Ruangan Laboratorium Fakultas Teknik Universitas Nurul Jadid

Berdasarkan hasil data perhitungan Berdasarkan hasil data perhitungan estimasi, semua ruangan di laboratorium fakultas teknik universitas nurul jadid pemakaian air conditioning sudah standart rata-rata pemakain pada ruangannya, hanya saja kurang stabil dikarenakan estimasi kebutuhannya tidak sesuai dengan hasil perhitungan british thermal unitnya (BTU/hr). Dilaboratorium fakultas teknik disetiap ruangan rata-rata menggunakan AC Merk Panasonic serta Merk LG. Selanjutnya peneliti kan menganalisa peluang penghematan dengan melakukan service/cleaning ac untuk mengambil sampel peluang penghematan diruangan laboratorium. Berikut gambar beserta tabel hasil data setelah melakukan service air conditioning untuk mencari peluang penghematannya. 
TABEL IX

DATA AIR CONDITIONING SETELAH DI SERVICE

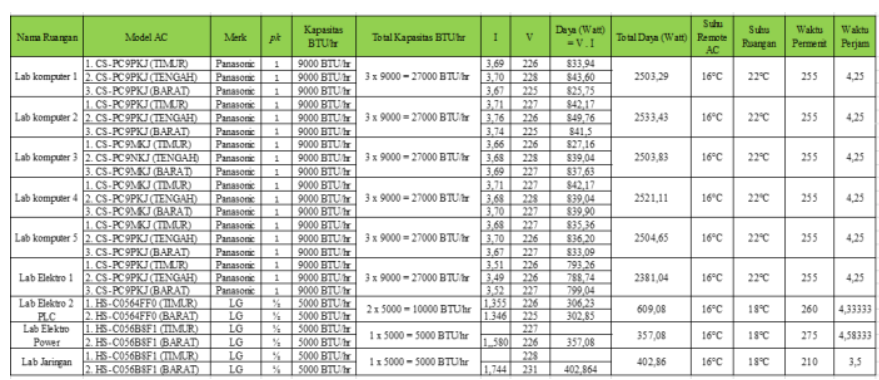

Sample Perhitungan Diruangan Laboratorium Komputer 1 Diketahui :

$$
\mathrm{T}=255 \text { Menit }=4,25 \mathrm{jam}
$$

$\Sigma \mathrm{W}=2503,29 \mathrm{~W}=2,50329 \mathrm{~kW}$

Jawab :

$k W h=W \times t$

$k W h=2,50329 \times 4,25$

$k W h=10,640$

Gedung Fakultas teknik Universitas Nurul Jadid memiliki daya yang terpasang sebesar 53.000 VA dengan golongan Sosial 2. Tarif dasar listrik untuk golongan S2 adalah sebesar Rp. 900/ kWh (sumber PLN 123). Jadi biaya yang di keluarkan oleh pihak lembaga untuk kebutuhan air conditioning pada ruangan laboratorium komputer 1 tersebut adalah 10,640 x $900=$ Rp. 9.576,23/hari. Dengan menggunakan 3 AC yang beroperasi dengan normal.

Jadi berdasarkan standar IKE bangunan indonesia yang ditetapkan oleh DEPDIKNAS, maka kriteria ruangan laboratorium komputer 1 memiliki nilai IKE sebesar 10,64 termasuk dalam katagori efisien dengan nilai standar IKE yaitu 7,92-12,08 PLC

Sample Perhitungan Diruangan Laboratorium Elektro 2

Diketahui :

$$
\mathrm{T}=260 \text { Menit }=4,333 \text { jam }
$$

$\Sigma \mathrm{W}=609,08 \mathrm{~W}=0,60908 \mathrm{~kW}$

Jawab :

$k W h=W \times t$

$k W h=0,60908 \times 4,333$

$k W h=2,639$

Gedung Fakultas Teknik Universitas Nurul Jadid memiliki daya yang terpasang sebesar 53.000 VA dengan golongan Sosial 2. Tarif dasar listrik untuk golongan S2 adalah sebesar Rp. 900/ kWh (sumber PLN 123). Jadi biaya yang di keluarkan oleh pihak lembaga untuk kebutuhan air conditioning pada ruangan laboratorium elektro 2 PLC tersebut adalah $2,639 \times 900=$ Rp. 2.375,22/hari. Dengan menggunakan 2 AC yang beroperasi dengan normal.

Jadi berdasarkan standar IKE bangunan indonesia yang ditetapkan oleh DEPDIKNAS, maka kriteria ruangan laboratorium elektro 2 PLC memiliki nilai IKE sebesar 2,63 termasuk dalam katagori efisien dengan nilai standar IKE yaitu $7,92-12,08$
Jadi kesimpulan dari perhitungan di atas ialah peluang penghematan di Ruangan Laboratorium Fakultas Teknik Universitas Nurul Jadid sebesar $12 \%$.

TABEL $\mathrm{X}$

JUMLAH PEMBIAYAAN PADA SISTEM AIR CONDITIONING SETELAH DI SERVICE RUANGAN LABORATORIUM FAKULTAS TEKNIK UNIVERSITAS NURUL JADID

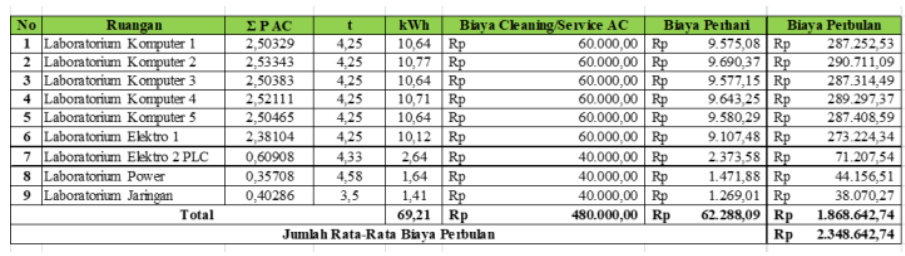

\section{KESIMPULAN}

Setelah mendapatkan hasil pengukuran pada Air Conditioning dan pengukuran ruangan disetiap Laboratorium Fakultas Teknik Universitas Nurul Jadid serta menganalisis data yang telah di tuangkan dalam bentuk gambar dan tabel, maka dapat di ambil beberapa kesimpulan berikut :

1. Berdasarkan hasil analisis, bahwa sebagian besar di setiap ruangan ber-AC Laboratorium Fakultas Teknik Universitas Nurul Jadid telah memenuhi Standar Nasional Indonesia (SNI) 03-6572-2001 rata-rata pemakaiannya.

2. Ketika melakukan observasi dan penelitian, peneliti menemukan beberapa AC yang tidak berfungsi dengan baik ada juga yang mati.

3. Berdasarkan hasil audit energi pengukuran intensitas konsumsi energi (IKE) Air Conditioning di Ruangan Laboratorium Fakultas Teknik Universitas Nurul Jadid, memiliki nilai IKE yang termasuk dalam katagori tidak hemat dengan nilai sebesar 99,034 kWh/bulannya. Kemudian setelah mencari peluang penghematannya memiliki nilai IKE yang termasuk dalam katagori efisien dengan nilai sebesar $64,86 \mathrm{kWH} /$ bulannya, yang telah ditetapkan oleh Standarisasi IKE Bangunan Indonesia yang Ditetapkan oleh DEPDIKNAS Tahun 2004. Dan Dan berdasarkan Peraturan Gubernur No. 38 tahun 2012. Serta SNI 03-6169 tahun 2000.

4. Jadi peluang penghematan di Ruangan Laboratorium Fakultas Teknik Universitas Nurul Jadid ialah sebesar $12 \%$.

5. Berdasarkan hasil audit energi pengukuran british thermal unit (BTU) Air Conditioning di Ruangan Laboratorium Fakultas Teknik Universitas Nurul Jadid, bahwa semua ruangan tersebut berada di bawah standarisasi nilai british thermal unit yang dibutuhkan sesuai ruangannya.

\section{UCAPAN TERIMA KASIH}

Terima kasih kepada semua pihak, terutama dosen pembimbing yang telah turut membantu dalam menyelesaikan artikel yang telah sayabuat. Dan terima kasih kepada Tim EEJ yang telah meluangkan waktu untuk membuat template ini. 


\section{REFERENSI}

[1] Bernadiktus, F., \& Hamzah, A. (2016). ANALISA EVALUASI INTENSITAS KONSUMSI ENERGI MELALUI AUDIT ENERGI LISTRIK DI GEDUNG REKTORAT UNIVERSITAS RIAU Fery. Jom Fteknik, 3(2), 1-11.

[2] Doddy, D. P. (2017). AUDIT ENERGI AIR CONDITIONER DI GEDUNG K.H. MAS MANSUR.

[3] Hasan, S., \& Rakhman, M. (n.d.). Syamsuri Hasan, Maman Rakhman, dan Agus Maulana, staf pengajar (dosen) Jurusan Pendidikan Teknik Mesin FPTK - UPI, Konsentrasi Teknik Refrigerasi Dan Tata Udara Artikel Audit Energi 1. 1-19.

[4] Hendradinata, \& Santosa, D. M. C. (2018). Kinerja Modifikasi Air Conditioning (AC) Dengan Unit Kondensor SPLIT HP Menggunakan Indoor Unit Air Conditioning (AC) SPLIT 2 HP. 5(1).

[5] Lukman, A. (2018). Audit Energi Pemakaian Air Conditioning (AC) Di Gedung Dinas Pekerjaan Umum Kab. Ketapang Propinsi Kalimantan Barat. 10, 1-5.

[6] Prof. Dr. Sugiyono. 2012. Metode Penelitian Kuantitatif, Kualitatif Dan R\&D. Bandung: Alfabeta.

[7] Purwito, Tadjuddin, \& Akbar. (2018). Audit Energi dan Analisis Peluang Penghematan Energi di PT . Daikin Air Conditioning Makassar. INTEk Jurnal Penelitian, 5(2), 115-121.

[8] Riyadi, S., \& Tambunan, J. M. (2013). Analisis peningkatan efisiensi penggunaan energi listrik pada sistem pencahayaan dan air conditioning di gedung graha mustika ratu. 107-121.

[9] Salpanio, R. (n.d.). AUDIT ENERGI LISTRIK PADA GEDUNG KAMPUS UNDIP PLEBURAN SEMARANG.

[10] Suntoro, D., S, R. D., \& Ahadi, K. (2018). Perhitungan Beban Pendinginan Pada Ruangan Di Perkantoran PT . Indonesia Power UPJP Pesanggaran Bali Cooling Capacity Calculation For Office Building. 17(1), 19-30.

[11] Syahrizal, I., Panjaitan, S., \& Udara, P. P. (2013). Analisis Konsumsi Energi Listrik Pada Sistem Pengkondisian Udara Berdasarkan Variasi Kondisi Ruangan ( Studi Kasus Di Politeknik Terpikat Sambas ). 5(1), $14-20$. 